\title{
Simulation of the steady-state behaviour of a new design of a single planar Solid Oxide Fuel Cell
}

\author{
Paulina Pianko-Oprych*, Tomasz Zinko, Zdzisław Jaworski \\ West Pomeranian University of Technology, Szczecin, Institute of Chemical Engineering and Environmental Protection \\ Processes, al. Piastów 42, 71-065 Szczecin, Poland \\ "Corresponding author: e-mail: paulina.pianko@zut.edu.pl
}

\begin{abstract}
The aim of the work was to develop a mathematical model for computing the steady-state voltage - current characteristics of a planar Solid Oxide Fuel Cell and to determine the performance of a new SOFC design. The design involves cross-flow bipolar plates. Each of the bipolar plates has an air channel system on one side and a fuel channel system on the other side. The proposed model was developed using the ANSYS-Fluent commercial Computational Fluid Dynamics (CFD) software supported by additional Fuel Cell module. The results confirm that the model can well simulate the diagonal current path. The effects of temperature and gas flow through the channels and a Membrane Electrode Assembly (MEA) structure were taken into account. It was shown that a significant increase of the MEA temperature at high current density can lead to hot spots formation and hence electrode damage.
\end{abstract}

Keywords: planar Solid Oxide Fuel Cell stack, Computational Fluid Dynamics, voltage - current characteristics, temperature distributions.

\section{INTRODUCTION}

Solid Oxide Fuel Cells (SOFCs) have been receiving more attention in the last years due to their high efficiency, reliable and either none or a very low impact on the environment ${ }^{1}$. However, to be able to utilize these devices in an effective way, mathematical models are needed, so that a new design of SOFC behaviour can be analyzed at different operating conditions ${ }^{2-4}$. Many of them ${ }^{5-6}$ attempted to apply multi-dimensional approaches to include complex interactions between the macro and micro structural parameters, multiphysics and electrochemical reactions taking place in the SOFC, both at the cell and stack levels. Some of them attempted to model electrodes in the volumes of the electron-ion conducting particles scattered throughout the electrodes ${ }^{7-9}$. Other researchers focused on numerical modelling of heat transfer in $\mathrm{SOFC}^{10-11}$. The high operating temperature of $600-800^{\circ} \mathrm{C}^{3-4}$, at which SOFCs operate, makes the temperature distribution measurement in the fuel cells difficult due to their complex design and sealing issues. Therefore, knowledge of the temperature distribution in Solid Oxide Fuel Cells obtained from the numerical modelling is crucial, since temperature has a significant impact on the combustion reaction mechanism and thus affect the power density. In addition, Santarelli et al. ${ }^{12}$ performed even more complex modelling to incorporate the kinetics of reforming reactions. Schluckner et al. ${ }^{13}$ carried out numerical and experimental investigation related to carbon deposition on the cell's anode. Many efforts have been also devoted to studying the internal reforming reactions such as Catalytic Partial Oxidation (CPOx), Steam Reforming (SR) or Water-Gas Shift Reaction (WGSR) ${ }^{5,14}$ or investigating the influence of the ion and electron transport resistance within the anode and cathode also accounting for the transport phenomena ${ }^{15}$. These studies improved the understanding of various transport processes taking place in SOFCs as well as the fuel cell performance.

However, one of the main challenges is still the optimum geometry design of the fuel cell plates. In this field, some efforts have been done by Bi et al. ${ }^{16}$ who investigated the effects of design parameters such as the channel height and manifold width on nonuniformity of fuel velocity distribution among channels. Also Cui et al. ${ }^{17}$ carried out modelling of tubular cells under three different modes of current collectors including either inlet or outlet or both inlet and outlet current collectors. The efficiency loss under the third type of current collectors was about 2 to 6 -fold lower than for those of just inlet or outlet collecting mode. Moreover, Lin et al. ${ }^{18}$ proposed a nonuniformity index to quantitative evaluation of the nonuniformity degree of fuel velocity distribution among channels in a planar SOFC unit. The CFD results showed that an increase in fuel velocity distribution nonuniformity led to a cell performance drop and the fuel velocity distribution was less uniform under lower cell voltage. It was also found that the fuel velocity was less uniform with lower working voltage and lower flow rate using the co-flow configuration instead of the counter-flow or using syngas as a fuel instead of hydrogen. The general conclusion from those studies was that it is necessary to develop a model for simulating the current path in the cell components in order to study the SOFC performance.

In this work, a three-dimensional model, consisting of fuel and air channels, anode, electrolyte and cathode layers, for a new design of an anode-supported planar Solid Oxide Fuel Cell with complex bipolar plates was developed to predict thermal and electrical fuel cell performance. The objective was identification of the importance of the electrochemical reactions and the impact of transport phenomena on the fuel cell efficiency. Further design optimization of the SOFCs is possible based on the local distributions of different parameters such as temperature, velocity, pressure, reactant concentrations as well as current density.

\section{MODEL DEVELOPMENT}

A Solid Oxide Fuel Cell consists of three major components: an cathode consists of a Strontium-Dopped 
Lanthanum Manganite (LSM), a thin Yttria-Stabilized Zirconia (YSZ) sheet, which acts as an electrolyte and an Nickel/Yttria-Stabilized Zirconia (Ni/YSZ) anode. The reactions for a planar SOFC fed with a hydrogen containing anode gas and an oxygen containing cathode gas were considered:

$\mathrm{H}_{2}+\mathrm{O}^{2-} \Leftrightarrow \mathrm{H}_{2} \mathrm{O}+2 \mathrm{e}^{-}$

$\frac{1}{2} \mathrm{O}_{2}+2 \mathrm{e}^{-} \Leftrightarrow \mathrm{O}^{2-}$

The products of these processes are direct current (DC) electricity, steam water and heat. Under normal operation, a planar SOFC typically produces voltage of $0.5-0.9[\mathrm{~V}]$.
In order to determine the voltage-current (V-I) characteristics of a new, anode-supported planar Solid Oxide Fuel Cell, a three-dimensional model for the planar fuel cell was developed in the CFD commercial software ANSYS - Fluent 15.0 with an additional Fuel Cell Tools module ${ }^{19-20}$. The simulations considered mass and heat transfer, fluid flow, species and energy transport as well as the electric field in the flow channels and in the porous electrodes.

The mass balance domains included anode, cathode and gas channels. In the anode the electrochemical reaction for pure hydrogen was considered (Eq. (1)), while in the cathode that for oxygen (Eq. (2)). The governing equations for mass balance are summarized in Table 1.

Table 1. The governing equations for mass balance

\begin{tabular}{|c|c|c|}
\hline Domain & Governing equations & \\
\hline \multirow{3}{*}{ Anode } & $\nabla\left(\rho_{\text {fuel }} \bar{v}_{H_{2}}-\rho_{\text {fuel }} x_{H_{2}} \sum_{k=1}^{N} D_{H_{2}, k}^{e f f} \nabla x_{i}\right)=R_{H_{2}}$ & (3) \\
\hline & $\nabla\left(\rho_{\text {fuel }} \bar{v}_{H_{2} \mathrm{O}}-\rho_{\text {fuel }} x_{\mathrm{H}_{2} \mathrm{O}} \sum_{k=1}^{N} D_{\mathrm{H}_{2} \mathrm{O}, \mathrm{e}}^{\text {eff }} \nabla x_{i}\right)=R_{\mathrm{H}_{2} \mathrm{O}}$ & (4) \\
\hline & $\nabla\left(\rho_{\text {fuel }} \bar{v}\right)=R_{\mathrm{H}_{2}}+R_{\mathrm{H}_{2} \mathrm{O}}$ & (5) \\
\hline \multirow[t]{2}{*}{ Cathode } & $\nabla\left(\rho_{\text {air }} \bar{v}_{O_{2}}-\rho_{\text {air }} x_{O_{2}} \sum_{k=1}^{N} D_{O_{2}, k}^{e f f} \nabla x_{i}\right)=R_{O_{2}}$ & (6) \\
\hline & $\nabla\left(\rho_{\text {air }} \bar{v}\right)=\mathrm{R}_{\mathrm{O}_{2}}$ & (7) \\
\hline \multirow{3}{*}{ Fuel channel } & $\nabla\left(\rho_{\text {fuel }} \bar{v}_{H_{2}}-\rho_{\text {fuel }} x_{H_{2}} \sum_{k=1}^{N} D_{H_{2}, k}^{\text {eff }} \nabla x_{i}\right)=0$ & (8) \\
\hline & \multirow{2}{*}{$\begin{array}{c}\nabla\left(\rho_{\text {fuel }} \bar{v}_{H_{2} \mathrm{O}}-\rho_{\text {fuel }} x_{\mathrm{H}_{2} \mathrm{O}} \sum_{k=1}^{N} D_{\mathrm{H}_{2} \mathrm{O}, k}^{\text {eff }} \nabla x_{i}\right)=0 \\
\nabla\left(\rho_{\text {fuel }} \overline{\mathrm{V}}\right)=0\end{array}$} & (9) \\
\hline & & (10) \\
\hline \multirow[t]{2}{*}{ Air channel } & \multirow{2}{*}{$\frac{\nabla\left(\rho_{\text {air }} \bar{v}_{O_{2}}-\rho_{\text {air }} x_{O_{2}} \sum_{k=1}^{N} D_{o_{2}, k}^{e f f} \nabla x_{i}\right)=0}{\nabla\left(\rho_{\text {air }} \bar{v}\right)=0}$} & (11) \\
\hline & & (12) \\
\hline
\end{tabular}

The mass diffusivity coefficient, $D_{i, k}^{\text {eff }}$, is approximated by the function of the electrode porosity, $\varepsilon$, tortuosity factor, $\tau$, and binary diffusion coefficient, $D_{\mathrm{i}, \mathrm{k}}$ (Eq. (13)):

$\mathrm{D}_{\mathrm{i}, \mathrm{k}}^{\mathrm{eff}}=\frac{\varepsilon}{\tau} \mathrm{D}_{\mathrm{i}, \mathrm{k}}$

The laminar flow in air/fuel channels was described by the Navier-Stokes equation, while the flow in porous electrodes was described by the Darcy's law. The governing equations for the momentum balance are summarized in Table 2.

Thermal energy was transferred by conduction and convection, the radiative heat transfer was neglected due to its low impact ${ }^{21}$. Heat source consisted of the chemical and electrochemical reaction enthalpies and Ohmic heat. The governing equations for energy balance for all domains are summarized in Table 3 .

The charge balance domains included anode, electrolyte, cathode and interconnectors. The governing equations for the charge balance are presented in Table 4. 
Table 2. The governing equations for momentum balance

\begin{tabular}{|l|c|c|}
\hline Domain & Governing equations & \\
\hline $\begin{array}{l}\text { Anode/ } \\
\text { Cathode }\end{array}$ & $\nabla\left(\varepsilon \rho_{\text {gas }} \overline{\mathrm{v}} \overline{\mathrm{v}}\right)=-\varepsilon \nabla p+\nabla\left[\varepsilon \mu_{\text {gas }}(\nabla \overline{\mathrm{v}}+(\nabla \overline{\mathrm{v}}))^{\top}\right]-\frac{2}{3} \varepsilon \nabla \overline{\mathrm{v}} l$ & $(14)$ \\
\hline Air/fuel channels & $\nabla\left(\rho_{\mathrm{gas}} \overline{\mathrm{V} V}\right)=-\nabla p+\nabla\left[\mu_{\text {gas }}(\nabla \overline{\mathrm{v}}+(\nabla \overline{\mathrm{v}}))^{\top}\right]$ & $(15)$ \\
\hline
\end{tabular}

Table 3. The governing equations for energy balance

\begin{tabular}{|l|c|c|}
\hline Domain & Governing equations \\
\hline Anode & $\nabla(-k \nabla T)=\frac{R_{H_{2, \text { anode }}} T\left(S_{H_{2} \mathrm{O}}-\frac{1}{2} S_{O_{2}}-S_{H_{2}}\right)}{M_{H_{2}}}+n_{H_{2, \text { anode }}} \mid Q_{H_{2, \text { anode-lec }}}+\frac{i_{\text {ion }}^{2}}{\sigma_{\text {anode, ion }}}+\frac{i_{\text {elec }}^{2}}{\sigma_{\text {anode,elec }}}$ \\
\hline Electrolyte & $\nabla(-\mathrm{k} \nabla \mathrm{T})=\frac{\mathrm{i}_{\text {ion }}^{2}}{\sigma_{\text {elec,ion }}}$ & (16) \\
\hline Cathode & $\nabla(-k \nabla T)=n_{O_{2, \text { cathode }}}\left|Q_{O_{2, \text { cathode-elec }}}\right|+\frac{i_{\text {ion }}^{2}}{\sigma_{\text {cathode,ion }}}+\frac{i_{\text {elec }}^{2}}{\sigma_{\text {cathode,elec }}}$ & (18) \\
\hline Inter-connectors & $\nabla(-\mathrm{k} \nabla \mathrm{T})=\frac{\mathrm{i}_{\text {elec }}^{2}}{\sigma_{\text {elec } \text { intercon }}}$ & (19) \\
\hline Air/fuel channels & $\nabla\left(-\mathrm{k} \nabla \mathrm{T}+\rho \mathrm{C}_{\mathrm{p}} \mathrm{T} \cdot \overline{\mathrm{v}}\right)=0$ & (20) \\
\hline
\end{tabular}

Table 4. The governing equations for charge balance

\begin{tabular}{|l|c|c|}
\hline Domain & Governing equations & lon conservation \\
\hline Anode & $-\nabla\left(\sigma_{\text {ion,anode }}^{\text {eff }} \nabla \phi_{\text {ion }}\right)=S_{\text {ion,anode }}$ & $(21)$ \\
\hline Electrolyte & $-\nabla\left(\sigma_{\text {ion,elec }}^{\text {eff }} \nabla \phi_{\text {ion }}\right)=S_{\text {ion,elec }}=0$ & $(22)$ \\
\hline Cathode & $-\nabla\left(\sigma_{\text {ion,cathode }}^{\text {eff }} \nabla \phi_{\text {ion }}\right)=S_{\text {ion,cathode }}$ & $(23)$ \\
\hline & Electron conservation & $(24)$ \\
\hline Anode & $-\nabla\left(\sigma_{\text {elec,anode }}^{\text {eff }} \nabla \phi_{\text {elec }}\right)=S_{\text {elec,anode }}$ & $(25)$ \\
\hline Electrolyte & $-\nabla\left(\sigma_{\text {elec,inter }}^{\text {eff }} \nabla \phi_{\text {elec }}\right)=\mathrm{S}_{\text {elec,inter }}=0$ & $(26)$ \\
\hline Cathode & $-\nabla\left(\sigma_{\text {elec,cathode }}^{\text {eff }} \nabla \phi_{\text {elec }}\right)=\mathrm{S}_{\text {elec,cathode }}$ & \\
\hline
\end{tabular}

The cell potential, $\phi_{\text {cell }}$, had the following form:

$\phi_{\text {cell }}=\phi_{\text {ideal }}-\phi_{\text {ele }}-\eta_{\text {act, anode }}-\eta_{\text {act, cathode }}-\eta_{\mathrm{s}}$

where: $\phi_{\text {ele }}$ is the Ohmic overpotential of the electrolyte, $\eta_{\text {act,anode }}$ and $\eta_{\text {act,cathode }}$ represent respectively the activation overpotential of the anode and cathode, $\eta_{\mathrm{s}}$ represents the Ohmic losses in the solid conduction regions such as current collectors, while $\phi_{\text {ideal }}$ represents the Nernst potential, $\phi_{\text {Nerst }}$, described by Eq. (28):

$\phi_{\text {Nernst }}=\frac{\Delta \mathrm{G}(\mathrm{T})}{2 \mathrm{~F}}+\frac{\mathrm{RT}}{2 \mathrm{~F}} \ln \frac{\mathrm{p}_{\mathrm{H}_{2}} \cdot \mathrm{p}_{\mathrm{O}_{2}}^{1 / 2}}{\mathrm{p}_{\mathrm{H}_{2} \mathrm{O}}}$

In order to estimate the values of the activation overpotentials for the anode and cathode the Newton method was used to solve the Butler-Volmer equation (29):

$i=i_{0, \text { eff }}\left[\exp \left(\frac{\alpha_{\text {anode }} n \eta_{\text {act, anode }} F}{R T}\right)-\exp \left(\frac{\alpha_{\text {cathode }} n \eta_{\text {act, cathode }} F}{R T}\right)\right]$

In Eq. (29), $i$ is the current density, $\mathrm{i}_{0, \text { eff }}$ is the effective exchange current density, $\alpha_{\text {anodea }}$ and $\alpha_{\text {cathode }}$ are anodic and cathodic transfer coefficients, respectively, and they were defined as 0.5 , because of the nearly universal assumption that there is a symmetric balance between the forward and backward reaction. In addition, $F$ is the Faraday's constant, $n$ is the number of electrons that are released per reaction, $R$ is the universal gas constant, $T$ is the absolute temperature. The effective exchange current density, $\mathrm{i}_{0, \mathrm{eff}}$, at the anode and cathode side can be written as:

$$
\begin{aligned}
& \mathrm{i}_{0, \text { eff }}^{\text {anode }}=i_{0, \text { ref }}^{\text {anode }}\left(\frac{\chi_{\mathrm{H}_{2}}}{\chi_{\mathrm{H}_{2}, \text { ref }}}\right)^{\gamma_{\mathrm{H}_{2}}}\left(\frac{\chi_{\mathrm{H}_{2} \mathrm{O}}}{\chi_{\mathrm{H}_{2} \mathrm{O}, \text { ref }}}\right)^{\gamma_{\mathrm{H}_{2} \mathrm{O}}} \\
& \mathrm{i}_{0, \text { eff }}^{\text {cathode }}=i_{0, \text { ref }}^{\text {cathode }}\left(\frac{\chi_{\mathrm{O}_{2}}}{\chi_{\mathrm{O}_{2}, \text { ref }}}\right)^{\gamma_{\mathrm{O}_{2}}}
\end{aligned}
$$

where $i_{0, \text { ref }}$ is the exchange current density at the reference condition, $\chi_{j}$ is the mole fraction and $\gamma_{j}$ is the concentration exponent for species $j$.

The species sources or sinks appearing in Eqs. (21-26) for the anodic (Eqs. (32), (33)) and cathodic (Eq. (34)) molar flux, respectively, are the following:

$S_{H_{2}}=-\frac{i}{2 F}$
$S_{H_{2} \mathrm{O}}=\frac{i}{2 F}$ 

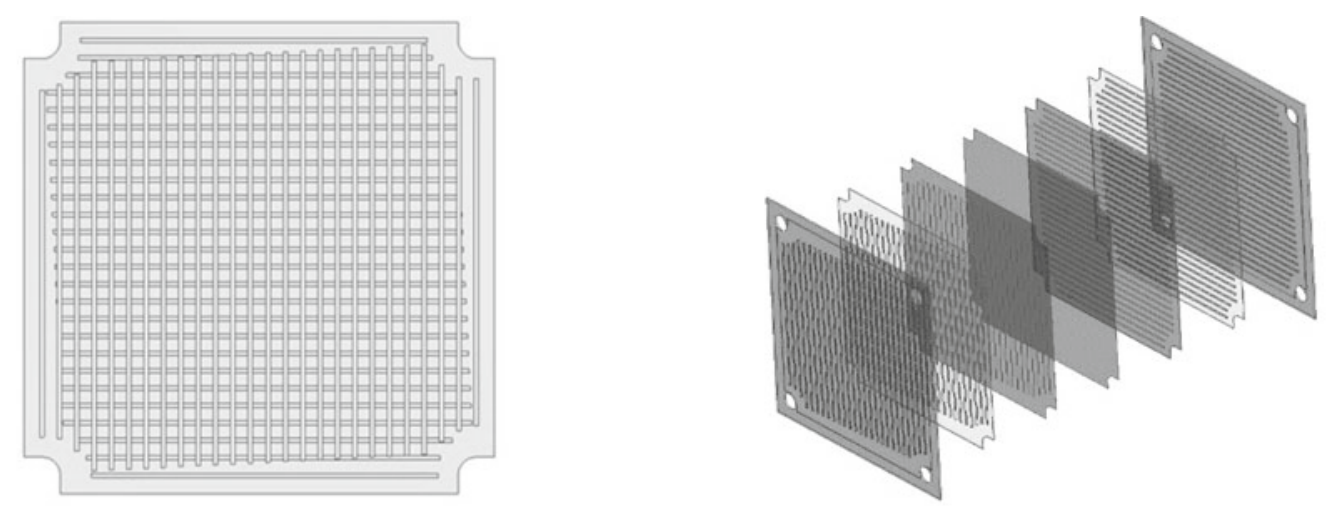

(a)

(b)

Figure 1. A schematic of the proposed planar SOFC design: (a) planar SOFC geometry with 26 ribs in the fuel channel, view from the cathode side, (b) single planar SOFC geometry divided into separate layers ${ }^{22}$

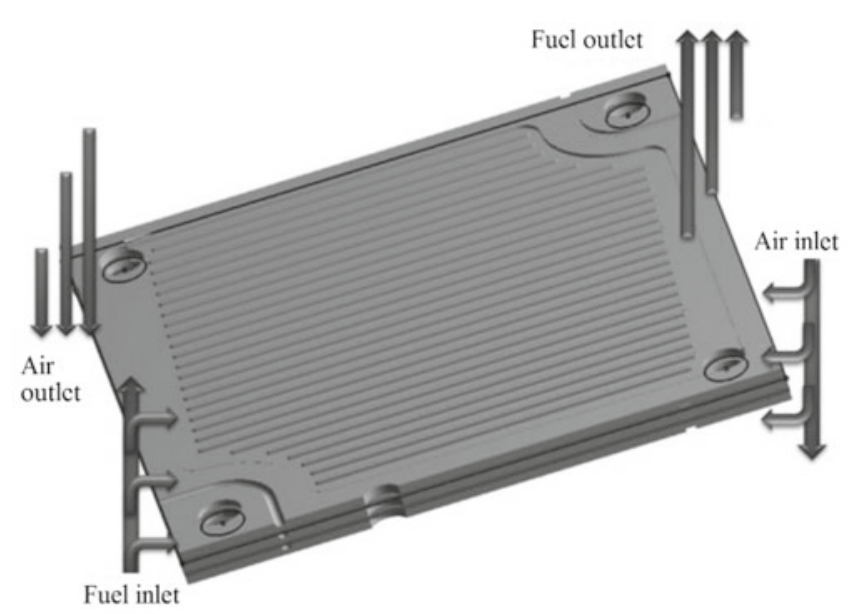

Figure 2. Flow field arrangements ${ }^{22}$

$S_{O_{2}}=-\frac{i}{4 F}$

A planar Solid Oxide Fuel Cell with cross-flow bipolar plates was used in the simulations. A schematic of the design proposed by Bossel ${ }^{22}$ is shown in Figure 1.

Flow channels were designed to connect two pairs of opposite orifices at four corners of the SOFC plates. Each of the bipolar plates had an air channel system on one side and a fuel channel system on the other side as shown in Figure 2. One pair of channels in adjacent plates was used for the air flow along the cathode electrode, the other one for the fuel flow along the anode of each cell. The basic dimensions of the fuel cell are presented in Table 5.
Table 5. Key geometry parameters ${ }^{22}$

\begin{tabular}{|l|c|c|}
\hline Parameter & Value & Dimension \\
\hline Anode thickness & 0.25 & $\mathrm{~mm}$ \\
\hline Electrolyte thickness & 0.01 & $\mathrm{~mm}$ \\
\hline Cathode thickness & 0.06 & $\mathrm{~mm}$ \\
\hline $\begin{array}{l}\text { Thickness of the } \\
\text { bipolar plate with } \\
\text { channel }\end{array}$ & 1 & $\mathrm{~mm}$ \\
\hline $\begin{array}{l}\text { Depth of the flow } \\
\text { channels }\end{array}$ & 0.35 & $\mathrm{~mm}$ \\
\hline $\begin{array}{l}\text { Diameter of the fuel } \\
\text { and air flow holes }\end{array}$ & 4.2 & $\mathrm{~mm}$ \\
\hline $\begin{array}{l}\text { Dimensions of fuel } \\
\text { cell, bipolar plates } \\
\text { and fuel/air channel }\end{array}$ & $60 \times 60$ & $\mathrm{~cm}^{2}$ \\
\hline $\begin{array}{l}\text { Active area of the fuel } \\
\text { cell }\end{array}$ & 27 & - \\
\hline $\begin{array}{l}\text { Number of ribs with } \\
\text { a different length }\end{array}$ & 26 & \\
\hline
\end{tabular}

The two electrode layers of the SOFC membrane-electrode assembly were resolved in the model and a thin electrolyte was considered as electrolyte interface. An unstructured 3D mesh was built in the ANSYS Meshing software in the fuel/air channels, anode and cathode domains. The mesh consisted of 890 thousands of computational cells. The operating conditions and material properties used in simulations are listed in Tables 6 and 7 , respectively.

The studied case was numerically solved using the following additional assumptions:

- steady state processes were considered,

- laminar flow was assumed in the porous electrodes,

- fuel and air were approximated as ideal gases,

- fuel and air channels were treated as adiabatic,

Table 6. Operating conditions used in simulations

\begin{tabular}{|l|c|c|}
\hline Domain region & Parameter & Value \\
\hline \multirow{3}{*}{ Air inlet } & Mass flow rate: & $1.7 \cdot 10^{-6} \mathrm{~kg} / \mathrm{s}$ \\
& Temperature: & $973 \mathrm{~K}$ \\
\cline { 2 - 3 } & Mass fraction of species: & $23.3 \% \mathrm{O}_{2}, 76.7 \% \mathrm{~N}_{2}$ \\
\cline { 2 - 3 } & Mass flow rate: & $4.9 \cdot 10^{-8} \mathrm{~kg} / \mathrm{s}$ \\
\cline { 2 - 3 } & Temperature: & $973 \mathrm{~K}$ \\
\cline { 2 - 3 } & Mass fraction of species: & $95.0 \% \mathrm{H}_{2}$ \\
\cline { 2 - 3 } Air outlet & Pressure: & $5.0 \% \mathrm{H}_{2} \mathrm{O}$ \\
& Temperature: & $1 \cdot 10^{6} \mathrm{~Pa}$ \\
\hline Outer current collector (anode side) surface & $973 \mathrm{~K}$ \\
\hline Outer current collector (cathode side) surface & Mass fraction of species: & $17.7 \% \mathrm{O}_{2}, 82.3 \% \mathrm{~N}_{2}$ \\
\hline Anode & Voltage tap surface: & $0 \mathrm{~V}$ \\
\hline Cathode & Current tap surface: & $0.7 \mathrm{~V}$ \\
\cline { 2 - 3 } & Exchange current density & $7460 \mathrm{~A} \cdot \mathrm{m}^{2}$ \\
\hline
\end{tabular}


Table 7. Material properties used in simulations

\begin{tabular}{|c|c|c|c|c|}
\hline Parameter & Anode & Electrolyte & Cathode & Current collectors \\
\hline Material & $\mathrm{Ni}-\mathrm{YSZ}$ & YSZ & LSM & - \\
\hline Density $\mathrm{kg} / \mathrm{m}^{3}$ & 7740 & 6000 & 5300 & 7450 \\
\hline Specified heat capacity J/kgK & 595 & 400 & 607 & 600 \\
\hline Thermal conductivity W/mK & 6.23 & 2.7 & 10 & 27 \\
\hline Resistivity Ohm $\mathrm{m}$ & - & 0.1 & - & - \\
\hline Electronic conductivity $1 / \mathrm{Ohm} \cdot \mathrm{m}$ & 30300 & - & 12800 & 769000 \\
\hline Anode-current collectors contact resistance $\mathrm{Ohm} \cdot \mathrm{m}^{2}$ & $1 \cdot 10^{-7}$ & - & $1 \cdot 10^{-8}$ & - \\
\hline Porosity & 0.3 & - & 0.3 & - \\
\hline
\end{tabular}

- radiation heat exchange between MEA and interconnectors was neglected,

- heat convection was neglected in the porous electrodes.

By keeping the adjustable parameters constant and varying the operating temperature, polarization curves at different temperatures were obtained. The CFD simulation results for the operating temperature of $700^{\circ} \mathrm{C}$ and for a usual range of the cell voltage from 0.3 to 1.1 $[\mathrm{V}]$ are presented in the next chapter.

\section{RESULTS AND DISCUSSION}

A particular interest in the employment of the CFD modelling is related to the species and temperature distributions within the new design of planar SOFC, analogous to experimental one $\mathrm{e}^{22}$ and particularly in the fuel and air flow channels. This is due to the fact that the SOFC performance strongly depends on the mass, heat and charge transport. Figure 3 depicts the mass fraction distributions respectively of hydrogen (a), water (b) and oxygen (c) at the electrolyte layer on the anode side. The mass fraction of hydrogen significantly changes diagonally between the fuel inlet and outlet. The fuel and air inlets are located at the left side (Fig. 2) of the fuel

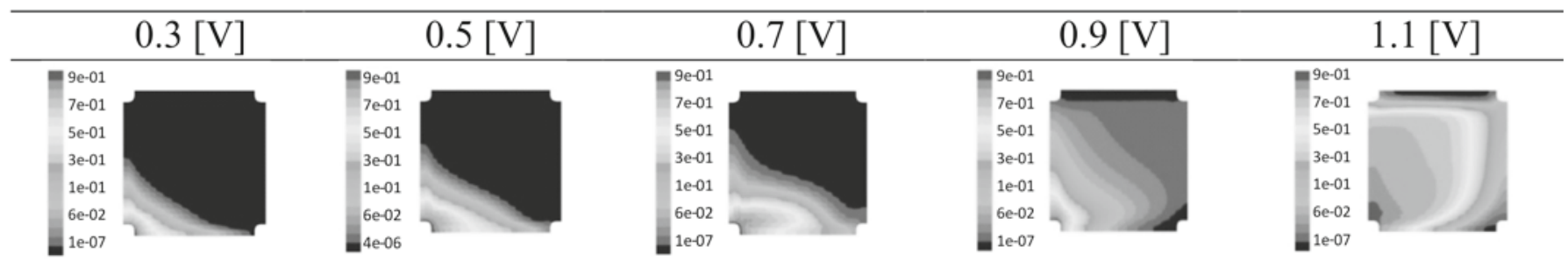
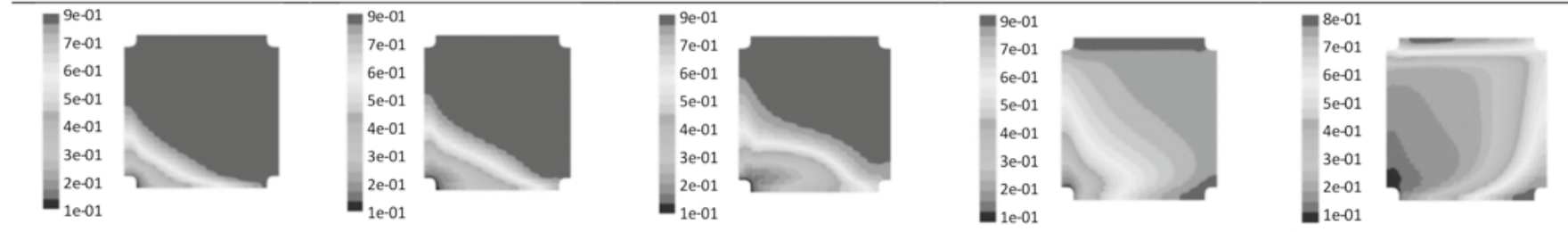

(b)
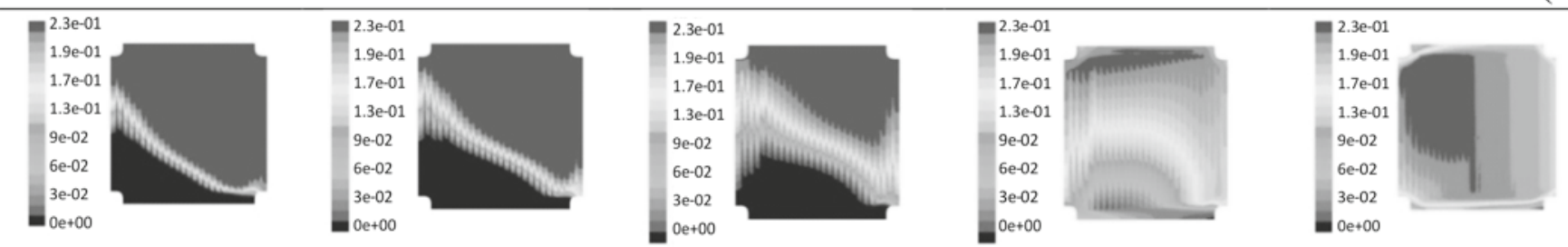

(c)

Figure 3. Species distributions in the electrolyte at the anode side $[\mathrm{kg} / \mathrm{kg}]$ : (a) mass fraction of hydrogen, (b) mass fraction of water, (c) mass fraction of oxygen

\begin{tabular}{|c|c|c|c|c|}
\hline $0.3[\mathrm{~V}]$ & $0.5[\mathrm{~V}]$ & $0.7[\mathrm{~V}]$ & $0.9[\mathrm{~V}]$ & $1.1[\mathrm{~V}]$ \\
\hline $\begin{array}{l}2.9 e+04 \\
2.4 e+04 \\
2.0 e+04 \\
1.2 e+04 \\
1.0 e+04 \\
7.1 e+03 \\
4.3 e+03 \\
0.0 e+00\end{array}$ & $\begin{array}{l}2.0 e+04 \\
1.7 e+04 \\
1.4 e+04 \\
1.1 e+04 \\
7.5 e+03 \\
4.9 e+03 \\
2.5 e+03 \\
0.0 e+00\end{array}$ & $\begin{array}{l}2.0 e+04 \\
1.7+04 \\
1.4 e+04 \\
1.1 e+04 \\
8.0 e+03 \\
6.0 e+03 \\
2.9 e+03 \\
0.0 e+00\end{array}$ & $\begin{array}{l}1.2 e+04 \\
9.7+03 \\
8.0 e+03 \\
6.7+03 \\
5.1+03+03 \\
3.4+03 \\
1.7+03 \\
0.0+0+00\end{array}$ & $\begin{array}{l}8.6 e+03 \\
7.6 .+03 \\
6.0+03 \\
5.2 e+03 \\
3.8 \mathrm{e}+03 \\
2.7 e+03 \\
1.7 e+03 \\
0.0 e+00\end{array}$ \\
\hline
\end{tabular}

Figure 4. Current density distributions in electrolyte at the cathode side $\left[\mathrm{A} / \mathrm{m}^{2}\right]$ 


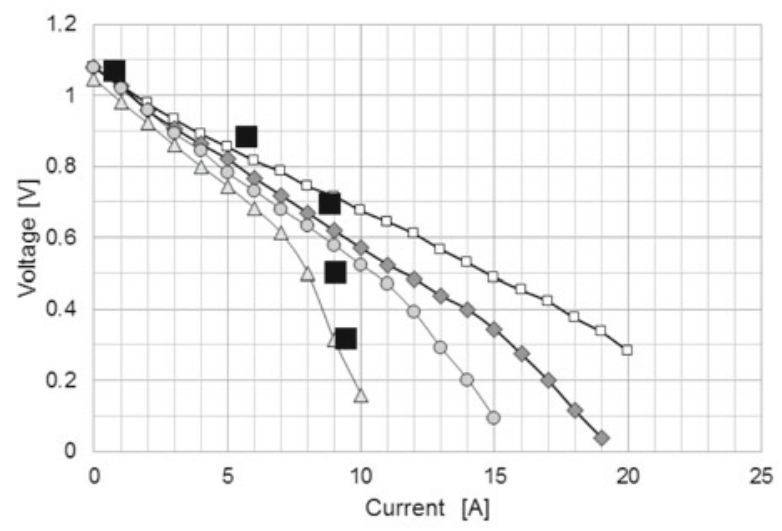

Figure 5. Comparison of the CFD results and experimental data ${ }^{22}$ of the V-I curves for a single planar SOFC

cell on its opposite sides; fuel on the bottom and air on the top side. In this specific region the water production due to electrochemical reaction becomes the strongest, while the mass fraction of hydrogen in fuel decreases along the channel due to electrochemical consumption. The mass fraction of hydrogen within the electrolyte is not uniform and differs for the operating voltage range values as it can be seen in Figure 3a.

The consumption rates of hydrogen and oxygen as well as the formation rates of water affect the current density distributions presented in Figure 4. Areas of the highest current density appear in the same regions, where the highest formation rates were noticed.

A comparison of the calculated voltage vs. power curves with the experimental results ${ }^{22}$ is presented in Figure 5.

The CFD curves correspond quite well with the experimental ones for the operating voltage of $0.7,0.9$ and $1.1[\mathrm{~V}]$, while at lower voltage values of 0.3 and $0.5[\mathrm{~V}]$ significant gradients in the electrical current were noticed.
High hydrogen utilization was observed from the voltage decreasing from $0.7[\mathrm{~V}]$, which may be a potential cause of the deviations from the experimental results. It seems that the cause of deviations from the experimental data $^{22}$ was local fuel starvation and reoxidation of the anode. To avoid widespread fuel starvation in the future and excessive heating a higher fuel feed rate should be probably used for an upper bound of current of 9 [A].

In addition, distributions of pressure, velocity and temperature in the fuel channel are shown in Figure $6 \mathrm{a}, \mathrm{b}$ and c, respectively. The pressure drop in the fuel channel ranged from 18.9 [Pa] to 12.9 [Pa] for higher voltage values as it can be seen in Figure 6a, while the same values were about ten times higher (not presented here) in the air channel. The second row of Figure $6 \mathrm{~b}$ shows the distribution of the velocity in the anodic channel. The hydrogen fuel enters the anode channel in the lower left corner at the velocity of $1.7[\mathrm{~m} / \mathrm{s}]$, then flows along 27 sub-channels with a different length and leaves the anode channel through the fuel outlet located at the upper right corner. The highest fuel velocity can be observed at the inlet, then it drops slightly at the inlet section, where the flow separation occurs and in the outlet section the velocity increases again. The velocity distributions within ribs were quite uniform with the mean value of $0.5[\mathrm{~m} / \mathrm{s}]$. The fuel velocity significantly changed in the inlet/outlet sections and areas between the ribs as it can be noticed in Figure $6 \mathrm{~b}$.

The lowest temperature was found near the fuel outlet at the upper right corner (Fig. 6c). The most surprising finding was that the highest temperature of the fuel was at the region of the air outlet at the lower right corner as well as in the region, where the formation of the products increased. The average temperature difference between the fuel inlet and outlet was equal to $150^{\circ} \mathrm{C}$,

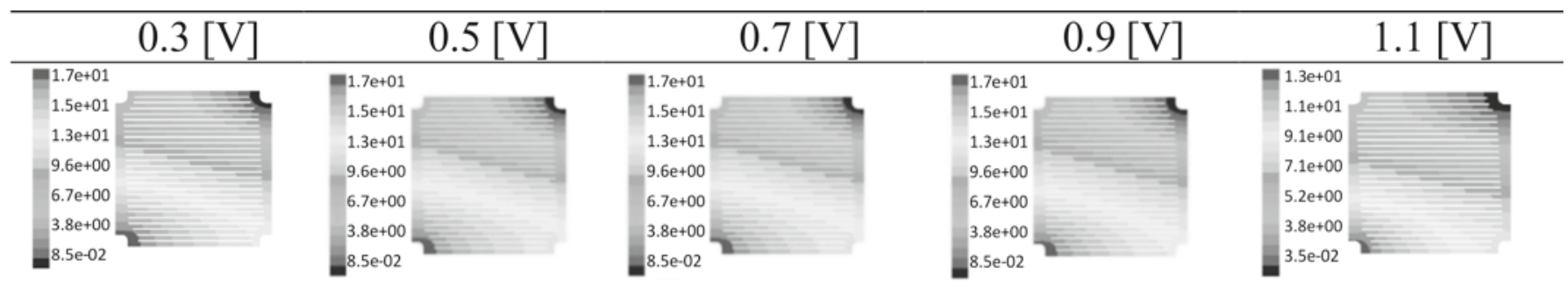
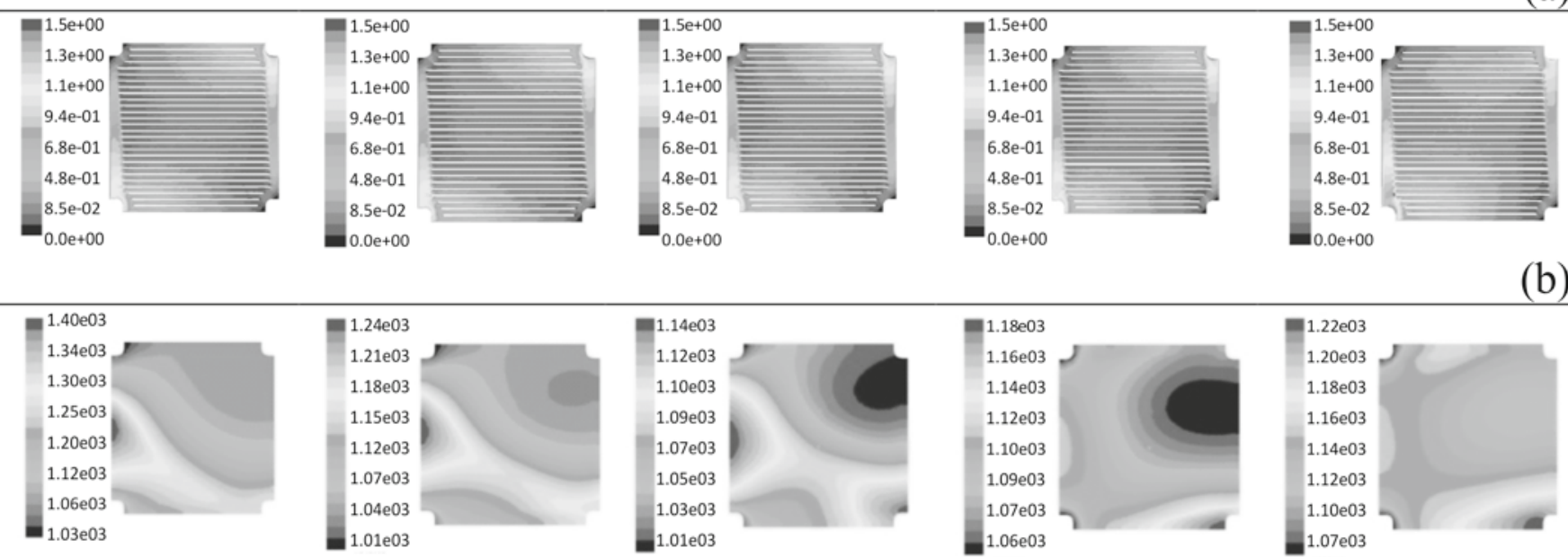

(b)

(c)

Figure 6. Distributions in the fuel channel of: (a) pressure [Pa], (b) velocity magnitude $[\mathrm{m} / \mathrm{s}]$, (c) temperature at the electrolyte - anode interface $[\mathrm{K}]$ 
with $230^{\circ} \mathrm{C}$ for the air channel. However, the temperature distributions are characterized by high nonuniformity, which may cause local thermal stresses and lead to fuel cell damage.

\section{CONCLUSIONS}

The CFD results were validated with experimental data and therefore the computational results are recognized as valuable and trustworthy. A reasonably good agreement of the predicted V-I curve with experiments was obtained. The simulation results directly contributed to the development process of the planar anode-supported SOFC. Moreover, the findings will be also used to optimize a new design of the bipolar plates developed under the framework of the SAFARI project.

\section{ACKNOWLEDGEMENTS}

The research programme leading to these results received funding from the European Union's Seventh Framework Programme (FP7/2007-2013) for the Fuel Cells and Hydrogen Joint Technology Initiative under Grant Agreement No [325323]. Acknowledgments are due to the partners of SAFARI project. The work was also financed from the Polish research funds awarded for the project No. 3043/7.PR/2014/2 of international cooperation within SAFARI in years 2014-2016.

\section{NOMENCLATURE}

$\mathrm{C}_{\mathrm{p}} \quad$ average specific heat, $\left[\mathrm{Jkg}^{-1} \mathrm{~K}^{-1}\right.$ ]

$\mathrm{D}_{\mathrm{i}, \mathrm{k}} \quad$ mass diffusivity coefficient, $\left[\mathrm{m}^{2} \mathrm{~s}^{-1}\right]$

$D_{i, k}^{e f f}$

effective diffusivity between species $i$ and $k$, $\left[\mathrm{m}^{2} \mathrm{~s}^{-1}\right]$

$F \quad$ Faraday's constant, $\left[\mathrm{Cmol}^{-1}\right]$

$\mathrm{G} \quad$ Gibbs free energy, $\left[\mathrm{Jmol}^{-1}\right]$

$\mathrm{i} \quad$ current density, $\left[\mathrm{Am}^{-2}\right]$

$i \quad$ species $\mathrm{H}_{2}, \mathrm{H}_{2} \mathrm{O}, \mathrm{O}_{2}$

I current, [A]

$\mathrm{i}_{0, \mathrm{eff}}$

$\mathrm{i}_{0, \text { ref }}$

$\mathrm{k}$

$M_{\mathrm{i}}$

$n$

$\mathrm{p}$

$Q_{\text {i }}$

$R$

$\mathrm{R}_{\mathrm{i}}$

$S_{\mathrm{i}}$

$\mathrm{T}$

$\frac{\mathrm{V}}{v_{i}}$

$x_{\mathrm{i}}$

CFD

CPOx

$\mathrm{DC}$

LSM

MEA

$\mathrm{Ni}$

SOFC

SR

\section{WGSR Water-Gas Shift Reaction \\ YSZ Yttria-Stabilized Zirconia}

\section{Greek symbols}

$\alpha_{\text {anode }} \quad$ anodic transfer coefficient, [-]

$\alpha_{\text {cathode }} \quad$ cathodic transfer coefficient, [-]

$\chi_{\mathrm{i}} \quad$ mole fraction, [mol mol${ }^{-1}$ ]

$\underset{\varepsilon}{\chi_{1}} \quad$ electrode porosity, [-]

$\phi_{\text {cell }} \quad$ cell potential, [V]

$\phi_{\text {ele }} \quad$ Ohmic overpotential of electrolyte, [V]

$\phi_{\text {ideal }} \quad$ ideal potential, [V]

$\phi_{\text {Nernst }} \quad$ Nernst potential, [V]

$\gamma_{\mathrm{i}} \quad$ concentration exponent for species $j,[-]$

$\mu \quad$ kinematic viscosity, [Pas]

$\rho_{\mathrm{i}} \quad$ density of species $i,\left[\mathrm{kgm}^{-3}\right]$

$\sigma_{\mathrm{i}} \quad$ electrical conductivity of species $i,\left[\mathrm{Sm}^{-1}\right]$

$\tau \quad$ tortuosity factor, [-]

$\eta_{\text {act,anode }}$ activation overpotential of anode, [V]

$\eta_{\text {act,cathode }}$ activation overpotential of cathode, [V]

$\eta_{\mathrm{s}} \quad$ Ohmic losses in the current collectors, [V]

\section{LITERATURE CITED}

1. Ullah, K.R., Akikur, R.K., Ping, H.W., Saidur, R., Hajimolana, S.A. \& Hussain, M.A. (2015). An experimental investigation on a single tubular SOFC for renevable energy based cogeneration system, Energy Conversion and Management 94, 139-149. DOI: 10.1016/j.enconman.2015.01.055.

2. Akhtar, N., Decent, S.P. \& Kendall, K. (2010). Numerical modelling of methane-powered micro-tubular, single chamber solid oxide fuel cell, J. Pow. Sour. 195, 7796-7807. DOI: 10.1016/j. jpowsour.2010.01.084.

3. Yang, Y., Du, X., Yang, L., Huang, Y. \& Xian, H. (2009). Investigation of methane steam reforming in planar porous support of solid oxide fuel cell, Appl. Therm. Eng. 29, 1106-1113. DOI: 10.1016/j.applthermaleng.2008.05.027.

4. Hussain, M., Li, X. \& Dincer, I. (2009). A general electrolyte-electrode-assembly model for the performance characteristics of planar anode-supported solid oxide fuel cells, J. Pow. Sour. 189, 916-928, DOI: 10.1016/j.jpowsour.2008.12.121.

5. Andersson, M., Yuan, J. \& Sunden, B. (2012). SOFC modeling considering electrochemical reactions at the active three phase boundaries, Inter. J. Heat Mass. Transfer 55, 773-777. DOI: 10.1016/j.ijheatmasstransfer.2011.10.032.

6. Goldin, G.M., Zhu, H., Kee, R.J., Bierschenk, D., Barnett, S.A. (2009). Multidimensional flow, thermal and chemical behavior in solid oxide fuel cell button cells, J. Pow. Sour. 187, 123-135. DOI: 10.1016/j.jpowsour.2008.10.097.

7. Shi, J. \& Xue, X. (2012). Inverse estimation of electrode microstructure distributions in NASA Bi-electrode supported solid oxide fuel cells, Chem. Eng. J. 182, 607-613. DOI: 10.1016/j.cej.2011.11.112.

8. Daneshvar, K., Dotelli, G., Cristiani, C., Pelosato, C. \& Santarelli, M. (2014). Modelling and parametric study of a single solid oxide fuel cell by Finite Element Method, Fuel Cells. 14, 189-199. DOI: 10.1002/fuce.201300235.

9. Bertrei, A., Nucci, B. \& Nicolella, C. (2013). Microstructural modeling for prediction of transport properties and electrochemical performance in SOFC composite electrodes, Chem. Eng. Sci. 101, 175-190. DOI: 10.1016/j.ces.2013.06.032.

10. Brus, G. \& Szmyd, J.S. (2008). Numerical modelling of radiative heat transfer in an internal indirect reforming type SOFC, J. Pow. Sour. 181, 8-16. DOI: 10.1149/1.2779314.

11. Zitouni, B., Ben Moussa, H., Oulmi, K., Asighi, S. \& Chetehouna, K. (2009). Temperature field, H2 and H2O mass transfer in SOFC single cell: electrode and electrolyte thickness effects, Inter. J. Hydrogen Energ., 34, 5032-5039. DOI: 10.1016/j. ijhydene.2008.12.085. 
12. Santarelli, M., Quesito, F., Novaresio, V., Guerra, C., Lanzini, A. \& Beretta, D. (2013). Direct reforming of biogas on Ni-based SOFC anodes: Modelling of heterogeneous reactions and validation with experiments, J. Pow. Sour. 242, 405-414. DOI: 10.1016/j.jpowsour.2013.05.020.

13. Schluckner, C., Subotic, V., Lawlor, V. \& Hochenauer, C. (2014). Three-dimensional numerical and experimental investigation of an industrial-sized SOFC fuelled by diesel reformat - Part I: creation of a base model for further carbon deposition modeling, Inter. J. Hydrogen Energ. 39, 19102-19118. DOI: 10.1016/j.ijhydene.2014.09.108.

14. Yuan, J. (2010). Simulation and analysis of multiscale transport phenomena and catalytic reactions in SOFC anodes, Chem. Prod. Proc. Model 5, 1934-2659. DOI: 10.2202/19342659.1450.

15. Andersson, M., Yuan, J. \& Sunden, B. (2010). Review on modeling development for multiscale chemical reactions coupled transport phenomena in solid oxide fuel cells. J. Appl. Energ. 87, 1461-1476. DOI: 10.1016/j.apenergy.2009.1.013.

16. Bi, W.X., Chen, D.F. \& Lin, Z.J. (2009). A key geometric parameter for the flow uniformity in planar solid oxide fuel cell stacks, Int. J. Hydrogen Energ. 34, 3873-3884. DOI: 10.1016/j. ijhydene.2009.02.071.

17. Cui, D., Liu, L., Dong, Y. \& Cheng, M. (2007). Comparison of different current collecting modes of anode supported micro-tubular SOFC through mathematical modeling J. Pow. Sour. 174, 246-254. DOI: 10.1016/j.powsourc.2007.08.094.

18. Lin, B., Shi, Y., Ni, M. \& Cai, N. (2015). Numerical investigation on impacts on fuel velocity distribution nonuniformity among solid oxide fuel cell units channels, Int. J. Hydrogen Energ. 40, 3035-3047. DOI: 10.1016/j.ijhydene.2014.12.088.

19. ANSYS Inc. ANSYS Fluent User's guide, V15.0 (2015). 20. ANSYS Inc. ANSYS Fluent Fuel Cell Modules Manual, V15.0 (2015).

21. Pianko-Oprych, P., Kasilova, E. \& Jaworski, Z. (2014). Quantification of the radiative and convective heat transfer processes and their effect on mSOFC by CFD modelling, Pol. J. Chem. Tech. 16, 2, 51-55. DOI: 10.2478/pjct-2014-0029.

22. Bossel, U. (2012). Rapid startup SOFC module, Energ. Proced. 28, 48-56. DOI: 10.1016/j.egypro.2012.08.039. 